\title{
Pre-sidedress Soil Nitrate Test for Sweet Corn
}

\author{
J.R. Heckman ${ }^{1}$ \\ Plant Science Department, P.O. Box 231, Cook College, New Brunswick, \\ NJ 08903 \\ W.T. Hlubik ${ }^{2}$ \\ Rutgers Cooperative Extension of Middlesex County, 390 George Street, 8th \\ Floor, New Brunswick, NJ 08901
}

\section{D.J. Prostak ${ }^{3}$ \\ Department of Entomology, P.O. Box 231, Cook College, New Brunswick, NJ 08903}

\section{J.W. Paterson ${ }^{4}$ \\ Rutgers Research and Development Center, 121 Northville Road, Bridgeton, NJ 08302-9499}

Additional index words. nitrogen, ammonium, manure nitrogen, soil mineral nitrogen, PSNT, Zea mays

\begin{abstract}
Research was conducted with sweet corn (Zea mays L.) to evaluate the presidedress soil $\mathrm{NO}_{3}$ test (PSNT) originally developed for use on field corn on a wide range of New Jersey soils. Soil $\mathrm{NO}_{3}-\mathrm{N}$ concentrations reflected differences in $\mathrm{N}$ availability due to manure or preplant $\mathrm{N}$ application. The relationship between soil $\mathrm{NO}_{3}-\mathrm{N}$ concentration and relative yield of marketable ears was examined using Cate-Nelson analysis to define the PSNT critical level. Soil $\mathrm{NO}_{3}-\mathrm{N}$ concentrations $>25 \mathrm{mg} \cdot \mathrm{kg}^{-1}$ were associated with relative yields at $\geq 92 \%$. The success rate for the PSNT critical level was $85 \%$ for predicting whether sidedress $\mathrm{N}$ was needed. Including $\mathrm{NH}_{4}-\mathrm{N}$ in the soil analysis did not improve the accuracy of the soil test for predicting whether sidedress $\mathrm{N}$ was needed. Although the PSNT is quite accurate in identifying $\mathrm{N}$-sufficient sites, it appears to offer only limited guidance in making $\mathbf{N}$-fertilizer rate predictions. The PSNT is most useful on manured soils, which frequently have sufficient $\mathrm{N}$. The test likely will help decrease the practice of applying "insurance" fertilizer $\mathrm{N}$ and the ensuing potential for $\mathrm{NO}_{3}$ pollution of the environment.
\end{abstract}

Requirements of sweet corn for sidedress $\mathrm{N}$ vary greatly from field to field. Recommending $\mathrm{N}$ fertilizer without information about the $\mathrm{N}$-supplying capability of the soil may result in using excess $\mathrm{N}$, which can contribute to $\mathrm{NO}_{3}$ pollution of water, or not supplying enough for economic yield. An ability to predict sweet corn responsiveness to $\mathrm{N}$ fertilizer before sidedressing would improve $\mathrm{N}$ management.

Received for publication 27 Dec. 1994. Accepted for publication 9 May 1995. The research reported in this publication was supported by the New Jersey Agricultural Expt. Station Project no. D-15-110-494 and the Northeast Region Sustainable Agriculture Research and Education Program. Use of trade names does not imply endorsement of the products named nor criticism of similar ones not named. We appreciate the technical assistance of Dennis Haines, Scott Hall, Kim Mayer, and Wendy Hill. The cost of publishing this paper was defrayed in part by the payment of page charges. Under postal regulations, this paper therefore must be hereby marked advertisement solely to indicate this fact.

${ }^{1}$ Extension Specialist in Soil Fertility.

${ }^{2}$ County Agricultural Agent.

${ }^{3}$ Extension Specialist in Pest Management

${ }^{4}$ Extension Specialist Emeritus in Soils and Crops.
Testing soils for $\mathrm{NO}_{3}$ to determine their $\mathrm{N}$ status has been a common practice for many years, but the practice has been limited to subhumid regions (Roberts et al., 1980). A soil test for available $\mathrm{N}$, called the pre-sidedress soil $\mathrm{NO}_{3}$ test (PSNT), now is gaining widespread acceptance in humid regions for use on field corn. The PSNT is an in-season soil test that measures the concentration of $\mathrm{NO}_{3}-\mathrm{N}$ in the surface $30 \mathrm{~cm}$ of soil when corn plants are 20 to $30 \mathrm{~cm}$ tall (Magdoff, 1991). The time of sampling is a key aspect of the soil test because it measures soil $\mathrm{NO}_{3}$ that accumulates in late spring just before significant $\mathrm{N}$ uptake by corn. "By sampling according to the growth of corn, the various factors that influence presence of available $\mathrm{N}$ are allowed to operate as long as possible before a sidedress fertilizer $\mathrm{N}$ decision must be made" (Magdoff, 1991). The critical PSNT values above which no sidedress fertilizer is recommended for field corn are generally in the lower range of 20 to $30 \mathrm{mg}$ $\mathrm{NO}_{3}-\mathrm{N} / \mathrm{kg}$ of soil (Magdoff, 1991).

Most researchers who have developed calibration data for the PSNT have only examined the relationship between soil $\mathrm{NO}_{3}-\mathrm{N}$ concentration and relative yield. However, researchers in Maryland (Meisinger et al., 1992) found that the relative yield relationship was better with soil $\left(\mathrm{NO}_{3}+\mathrm{NH}_{4}\right)-\mathrm{N}$ than with
$\mathrm{NO}_{3}-\mathrm{N}$ alone. Researchers in Tasmania (Salardini et al., 1992) found that measuring soil $\left(\mathrm{NO}_{3}+\mathrm{NH}_{4}\right)-\mathrm{N}$ concentration to a $40-\mathrm{cm}$ depth is a promising method to predict sweet corn yield response to fertilizer $\mathrm{N}$.

Our experience using the PSNT on New Jersey field corn agrees with studies in other states that have found using this soil test reduces fertilizer $\mathrm{N}$ application by about onethird. The largest $\mathrm{N}$ fertilizer savings from using the PSNT generally occur on manured land (Klausner et al., 1993; Meisinger et al., 1992). The oversupply of nutrients from large poultry and dairy operations in the eastern United States may promote increased application of manures to land used for sweet corn production.

Although the PSNT seems to have potential to improve $\mathrm{N}$ management in crops other than field corn, research to calibrate the PSNT and to evaluate its performance is needed before it can be used with sweet corn. Several crop features different from field corn could influence the adaptation of the PSNT to sweet corn. Harvest of sweet corn at an earlier physiological growth stage than field corn and a generally smaller plant size and plant population could affect the PSNT critical level. The importance of ear size also may be a factor influencing PSNT reliability on sweet corn.

We examined the relationships between relative sweet corn yield and soil mineral $\mathrm{N}$ before sidedressing. Our objective was to evaluate the usefulness of the PSNT to accurately identify $\mathrm{N}$ responsive and nonresponsive sweet corn fields from a diversity of soils, climates, and management histories in New Jersey.

\section{Materials and Methods}

A total of 61 PSNT field calibration experiments were conducted in New Jersey from 1991 to 1994 . Soil and crop characteristics measured included soil mineral $\mathrm{N}$ and sweet corn yield. Sites were chosen to represent a wide range of soils and management histories in two physiographic regions in New Jersey (Atlantic coastal plain and Piedmont). All soils were well drained and had surface textures ranging from sandy loams to silt loams. Although not measured in this experiment, typical soil organic matter content levels in New Jersey range from 5 to $20 \mathrm{~g} \cdot \mathrm{kg}^{-1}$ in sandy loams and from 25 to $35 \mathrm{~g} \cdot \mathrm{kg}^{-1}$ in silt loams. Arrangements were made to have manure applied and incorporated within 1 to 4 weeks before planting at $40 \%$ of the sites. Some of the sites had a long history of manure use. Previous crops among the sites were diverse and included various types of field crops, vegetable crops, legume and grass cover crops, and fallow. At $34 \%$ of the sites, $\mathrm{NH}_{4} \mathrm{NO}_{3}$ was broadcast (45 kg N/ha) and incorporated by disking immediately before planting. No $\mathrm{N}$ was added to the remaining $26 \%$ of the sites before planting. Conventional tillage was used at all sites. Soil $\mathrm{pH}$ and $\mathrm{P}, \mathrm{K}$, and micronutrient fertility levels were managed according to Rutgers' commercial vegetable production recommendations. At planting, starter fertilizer was applied near the seed at a rate that supplied 
Soll Management, Fertilization, \& Irrigation

$22 \mathrm{~kg} \mathrm{~N} / \mathrm{ha}$. Planting, weed, and insect control were performed by farmers or research station technicians. Sites with poor plant populations were not used for PSNT calibration. Row widths were either 76 or $91 \mathrm{~cm}$, and plant populations at time of sidedressing averaged 56,000 plants/ha and ranged from 44,000 to 63,000 plants/ha among the calibration sites. The design was a randomized complete block with four replications. At 40 of the sites, $\mathrm{N}$ rates of $0,45,90,135$, and $180 \mathrm{~kg} \mathrm{~N} /$ ha were sidedressed. The other sites included only the 0 and $180 \mathrm{~kg} \mathrm{~N} / \mathrm{ha}$ sidedress rates. Whenever a site received $45 \mathrm{~kg} \mathrm{~N} /$ ha broadcast as $\mathrm{NH}_{4} \mathrm{NO}_{3}$ before planting, the highest rate of sidedress $\mathrm{N}$ was limited to $135 \mathrm{~kg} \mathrm{~N} / \mathrm{ha}$. Sidedress N was applied by hand as $\mathrm{NH}_{4} \mathrm{NO}_{3}$. Individual plot size was at least six rows wide and ranged from 12 to $15 \mathrm{~m}$ long. When plants were $30 \mathrm{~cm}$ tall at the whorl, PSNT soil samples were taken by collecting eight cores $(2 \mathrm{~cm}$ in diameter $\times 30$ $\mathrm{cm}$ deep) between the rows of each control plot when plants were $30 \mathrm{~cm}$ tall at the whorl. The soil cores were composited by plot and spread in a thin layer $(1 \mathrm{~cm}$ thick $)$ to air-dry at room temperature for $48 \mathrm{~h}$ immediately after collection. The air-dried soil was crushed to pass a 2-mm screen and was thoroughly mixed. Five grams of soil were extracted with $50 \mathrm{ml}$ of $2 \mathrm{M} \mathrm{KCl}$ by shaking for $30 \mathrm{~min}$. Nitrate and $\mathrm{NH}_{4}$ concentrations in the extract were determined by using an autoanalyzer (Technicon Industrial Systems, Tarrytown, N.Y.). Sweet corn was harvested when kernels showed a transition from clear to milky fluid.

Yield of snapped, unhusked ears was determined by harvesting $18.2 \mathrm{~m}$ of row length from the center rows of each plot. Primary, secondary, and tertiary (when present) ears were harvested and graded as marketable or nonmarketable according to ear length; minimum length was $17 \mathrm{~cm}$. Total weight of fresh ear production and number and weight of marketable ears were determined. Relative yields for these characteristics were defined as the control yield, expressed as a percentage of the maximum yield observed for the sidedress $\mathrm{N}$ rates used within a field calibration site. The relationships between soil mineral $\mathrm{N}$ and relative yield were examined using Cate-Nelson analysis (Cate and Nelson, 1971) and linear regression.

\section{Results and Discussion}

Relative sweet corn yields (yield without sidedress $\mathrm{N}$, expressed as a percentage of maximum yield with sidedress $\mathrm{N}$ ) were calculated for number of marketable ears, fresh weight of marketable ears, and total fresh ear production. The reason for evaluating yield by these methods is that sweet corn is marketed both ways. Total fresh (primary + secondary + tertiary) ear production is a measure of yield response to $\mathrm{N}$ without the subjective influence of market grading.

The soil mineral $\mathrm{N}$ and relative yield data in Table 1 provide an overview of the sweet corn production systems. Field sites where manure or $\mathrm{NH}_{4} \mathrm{NO}_{3}$ fertilizer was applied before planting generally had higher soil $\mathrm{NO}_{3}-\mathrm{N}$
Table 1. Average soil mineral $\mathrm{N}$ and relative yield for the sweet corn production systems studied.

\begin{tabular}{|c|c|c|c|c|c|c|c|c|c|c|}
\hline \multicolumn{2}{|c|}{$\begin{array}{c}\text { Preplant } \\
\text { amendment }\end{array}$} & \multirow[b]{2}{*}{$\mathrm{n}$} & \multicolumn{4}{|c|}{$\begin{array}{c}\text { Soil mineral N } \\
\left(\mathrm{mg} \cdot \mathrm{kg}^{-1}\right)^{\mathrm{z}}\end{array}$} & \multicolumn{4}{|c|}{$\begin{array}{c}\text { Relative yield }(\%)^{y} \\
\text { marketable ears }\end{array}$} \\
\hline Manure & $\overline{\mathrm{NH}_{4} \mathrm{NO}_{3}}$ & & $\mathrm{NO}_{3}-\mathrm{N}$ & $\mathrm{SD}^{\mathrm{x}}$ & $\mathrm{NH}_{4}{ }^{+}-\mathrm{N}$ & $\overline{\mathrm{SD}}$ & No. & SD & Fresh wt & SD \\
\hline- & - & 24 & 12 & 7 & 6 & 2 & 75 & 23 & 73 & 24 \\
\hline+ & - & 17 & 26 & 12 & 6 & 1 & 97 & 8 & 95 & 8 \\
\hline - & + & 13 & 16 & 10 & 6 & 1 & 80 & 20 & 79 & 20 \\
\hline+ & + & 7 & 31 & 15 & 6 & 2 & 99 & 7 & 98 & 7 \\
\hline
\end{tabular}

${ }^{2}$ Soil test concentration in the surface $30 \mathrm{~cm}$ of soil when plants were $30 \mathrm{~cm}$ tall.

'Relative yield is the yield obtained without sidedress fertilizer $\mathrm{N}$ expressed as a percentage of the maximum yield achieved with sufficient sidedress fertilizer $\mathrm{N}$.
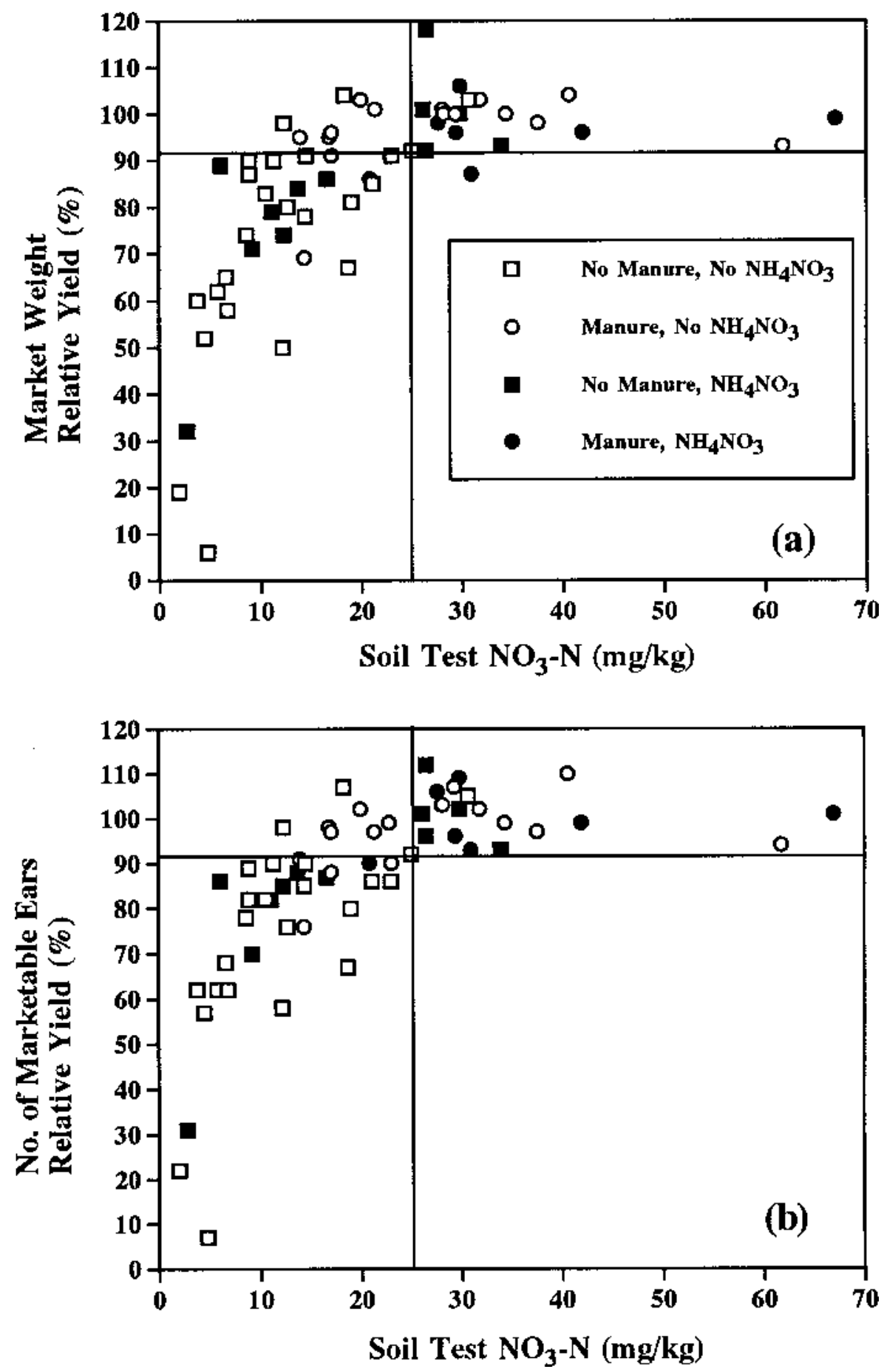

Fig. 1. Relative sweet corn yield as a function of soil $\mathrm{NO}_{3}-\mathrm{N}$ concentration in surface $30 \mathrm{~cm}$ of soil when plants were $30 \mathrm{~cm}$ tall; (a) marketable weight, (b) number of marketable ears. 
levels at the 30-cm-tall plant growth stage. In contrast, soil $\mathrm{NH}_{4}-\mathrm{N}$ levels were similar among production systems regardless of whether manure or $\mathrm{NH}_{4} \mathrm{NO}_{3}$ was added. This similarity in $\mathrm{NH}_{4}-\mathrm{N}$ concentrations implies that $\mathrm{NH}_{4}-\mathrm{N}$ was rapidly nitrified and that differences in soil mineral N-supplying capacity can be determined largely by measuring $\mathrm{NO}_{3}$ alone (Blackmer et al., 1989; Meisinger et al., 1992). When manure was applied, an average relative yield of $96 \%$ was achieved compared with only $75 \%$ on nonamended soils.

The relationship between the soil $\mathrm{NO}_{3}-\mathrm{N}$ concentration and relative yields was tested with the Cate-Nelson statistical analysis by partitioning data into $\mathrm{N}$-responsive and nonresponsive sites (Fig. $1 \mathrm{a}$ and b). The horizontal line (Fig. 1) was placed at an acceptable relative yield level of $92 \%$, and the vertical line defines the critical soil $\mathrm{NO}_{3}-\mathrm{N}$ concentration. The intersection of the two lines was drawn to minimize the number of observations in the upper left quadrant (incorrect predictions of a need for sidedress $\mathrm{N}$ ) and the lower right quadrant (incorrect predictions that sidedress $\mathrm{N}$ is not needed). The critical soil $\mathrm{NO}_{3}-\mathrm{N}$ concentration was similar whether marketable ear count or market weight was used to calculate relative yield (Fig. $1 \mathrm{a}$ and b). With a critical level of $25 \mathrm{mg} \mathrm{NO}_{3}-\mathrm{N} / \mathrm{kg}$, the PSNT would have predicted whether sidedress $\mathrm{N}$ was needed correctly at $85 \%$ of the sites. At $12 \%$ of the sites, the soil test would predict a need for sidedress $\mathrm{N}$ incorrectly, which would result in overfertilization. Only one was clearly in the lower right quadrant, but it was at least close to $90 \%$ maximum yield. This successful prediction rate for sweet corn is essentially the same as reported for use of the PSNT on field corn in Pennsylvania and New York (Fox et al., 1989; Klausner et al., 1993). The critical soil $\mathrm{NO}_{3}-\mathrm{N}$ concentration for sweet corn also is close to the critical value identified for field corn in New Jersey (unpublished data). Other researchers (Binford et al., 1992; Blackmer et al., 1989; Fox et al., 1989; Klausner et al., 1993; Magdoff et al., 1984; Meisinger et al., 1992) working in humid regions with field corn found that 20 to $25 \mathrm{mg} \mathrm{NO}-\mathrm{N} / \mathrm{kg}$ was sufficient for near-maximum yield. Sweet corn grown on a soil with low organic matter content in a semiarid region of Washington state produced a $95 \%$ relative yield with $30 \mathrm{mg}$ $\mathrm{NO}_{3}-\mathrm{N} / \mathrm{kg}$ in the surface $120 \mathrm{~cm}$ of soil (Roberts et al., 1980).

The relationship between soil $\mathrm{NO}_{3}-\mathrm{N}$ concentration and relative yield based on total fresh ear production (Fig. 2) was similar to that exhibited using relative yields of marketable sweet corn (Fig. 1). This indicates that the critical level is probably unrelated to the specific criteria used for grading marketable ears. The findings of this study, therefore, should be applicable to sweet corn grown for fresh market or processing, which may use different yield components.

The relationship between relative yields and soil mineral $\mathrm{N}\left(\mathrm{NO}_{3}+\mathrm{NH}_{4}\right)-\mathrm{N}$ revealed a critical $\left(\mathrm{NO}_{3}+\mathrm{NH}_{4}\right)-\mathrm{N}$ value of $31 \mathrm{mg} \cdot \mathrm{kg}^{-1}$ that was associated with relative yields of $92 \%$ (Fig. $3 \mathrm{a}$ and b). Working with field corn in

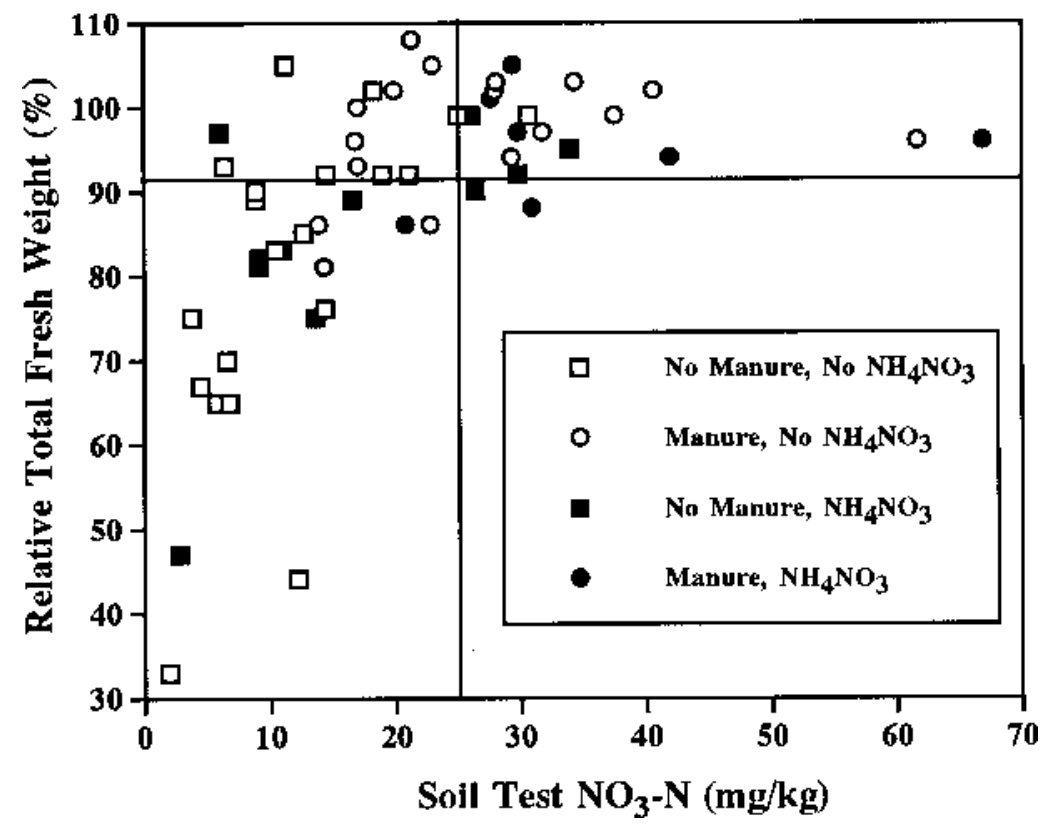

Fig. 2. Relative total fresh weight of primary, secondary, and tertiary ears of sweet corn as a function of soil $\mathrm{NO}_{3}-\mathrm{N}$ concentration in surface $30 \mathrm{~cm}$ of soil when plants were $30 \mathrm{~cm}$ tall.
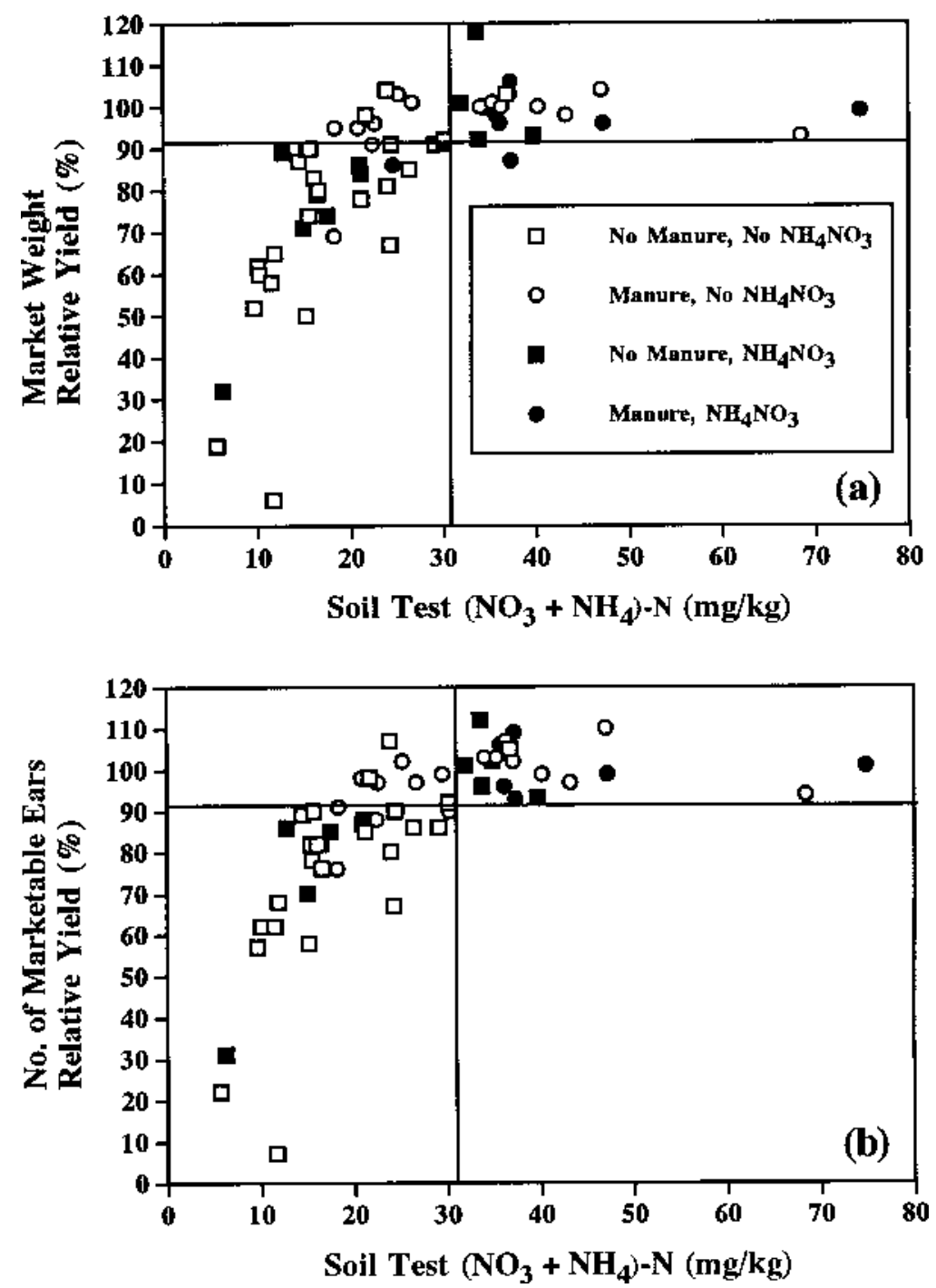

Fig. 3. Relative sweet corn yield as a function of soil $\left(\mathrm{NO}_{3}+\mathrm{NH}_{4}\right)-\mathrm{N}$ concentration in surface $30 \mathrm{~cm}$ of soil when plants were $30 \mathrm{~cm}$ tall; (a) marketable weight, (b) number of marketable ears. 
Maryland, Meisinger et al. (1992) found that including both $\mathrm{N}$ sources improved the relationship with crop yield. They reported a critical soil $\left(\mathrm{NO}_{3}+\mathrm{NH}_{4}\right)-\mathrm{N}$ concentration of 27 $\mathrm{mg} \cdot \mathrm{kg}^{-1}$ for field corn. In New Jersey, the soil $\mathrm{NH}_{4}-\mathrm{N}$ concentration averaged $6 \mathrm{mg} \cdot \mathrm{kg}^{-1}$ and showed little variation over a wide range of soils and production systems (Table 1). Because sweet corn has a wide planting window and often is planted later than field corn, warmer soils often would permit more rapid and complete nitrification. Thus, the usefulness of soil $\mathrm{NH}_{4}-\mathrm{N}$ data is limited for predicting the need for sidedressing sweet corn.

A wide range of relative yields were associated with low PSNT values (Figs. 1 and 2). Below the soil test critical levels, there was a poor correlation between relative yield and soil $\mathrm{NO}_{3}-\mathrm{N}\left(\mathrm{y}=2.36 \mathrm{x}+46, \mathrm{x} \leq 25, r^{2}=0.46\right)$ and $\left(\mathrm{NO}_{3}+\mathrm{NH}_{4}\right)-\mathrm{N}\left(\mathrm{y}=2.36 \mathrm{x}+33, \mathrm{x} \leq 31, r^{2}\right.$ $=0.51)$ concentration. The data indicate that when concentrations are below the critical level, the PSNT likely does not predict relative yield accurately. Although the PSNT is quite accurate in identifying $\mathrm{N}$-sufficient sites, it seems to offer only limited guidance in making $\mathrm{N}$-fertilizer rate predictions for sweet corn. This finding agrees with the observations of Fox et al. (1989), Meisinger et al. (1992), and Klausner et al. (1993) regarding the use of the PSNT for field corn.

The inability of the PSNT to provide satisfactory $\mathrm{N}$ recommendations at some sites may be due to soils having unequal rates of $\mathrm{N}$ mineralization. If the mineralization rate is slow before the PSNT soil sample is taken and later changes to allow significant amounts of
$\mathrm{N}$ to be made available, the PSNT may recommend excessive $\mathrm{N}$ fertilizer. Losses of $\mathrm{NO}_{3}$ by leaching, denitrification, or both also may influence the accuracy of the PSNT. These problem situations with using the PSNT were discussed in a review by Magdoff (1991).

\section{Summary and Conclusion}

Concentrations of $\mathrm{NO}_{3}-\mathrm{N}$ and $\left(\mathrm{NO}_{3}+\right.$ $\mathrm{NH}_{4}$ )-N in the surface $30 \mathrm{~cm}$ of soil when sweet corn plants are $30 \mathrm{~cm}$ tall can be used to predict whether a response to sidedress $\mathrm{N}$ fertilizer is likely. Nonresponsive sites, or sites with relative yields at $\geq 92 \%$ without sidedressing, were associated with soil $\mathrm{NO}_{3}-\mathrm{N}$ concentrations $>25 \mathrm{mg} \mathrm{N} / \mathrm{kg}$ and soil $\left(\mathrm{NO}_{3}+\right.$ $\left.\mathrm{NH}_{4}\right)-\mathrm{N}>31 \mathrm{mg} \mathrm{N} / \mathrm{kg}$. Including $\mathrm{NH}_{4}-\mathrm{N}$ in the soil analysis did not improve the accuracy of the soil test for predicting whether sidedress $\mathrm{N}$ was needed. The accuracy of predicting relative yields from soil test levels below the critical levels was limited by poor correlations with soil $\mathrm{NO}_{3}-\mathrm{N}\left(r^{2}=0.46\right)$ and soil $\left(\mathrm{NO}_{3}+\right.$ $\left.\mathrm{NH}_{4}\right)-\mathrm{N}\left(r^{2}=0.51\right)$.

Widespread use of the PSNT on field corn can be extended to use with sweet corn. The PSNT would be most useful on manured soils (or other soils with a potential to mineralize significant amounts of $\mathrm{N}$ ), which frequently can be identified with the soil test as having sufficient $\mathrm{N}$. This practice may allow greater beneficial use of manures on land used for sweet corn production. Using the PSNT also may decrease the practice of applying "insurance" fertilizer $\mathrm{N}$ and the potential for $\mathrm{NO}_{3}$ contamination of water supplies.

\section{Literature Cited}

Binford, G.D., A.M. Blackmer, and M.E. Cerrato. 1992. Relationships between corn yields and soil nitrate in late spring. Agron. J. 84:53-59.

Blackmer, A.M., D. Potter, M.E. Cerrato, and J. Webb. 1989. Correlations between soil nitrate concentrations in late spring and corn yield in Iowa. J. Prod. Agr. 2:103-109.

Cate, R.B. and L.A. Nelson. 1971. A simple statistical procedure for partitioning soil test correlation into two classes. Soil Sci. Soc. Amer. Proc. 35:658-660.

Fox, R.H., G.W. Roth, K.V. Iversen, and W.P. Piekielek. 1989. Soil and tissue nitrate tests compared for predicting soil nitrogen availability to corn. Agron. J. 81:971-974.

Klausner, S.D., W.S. Reid, and D.R. Bouldin. 1993. Relationship between late spring soil nitrate concentrations and corn yields in New York. J. Prod. Agr. 6:350-354.

Magdoff, F.R. 1991. Understanding the Magdoff pre-sidedress nitrate test for corn. J. Prod. Agr. 4:297-305.

Magdoff, F.R., D. Ross, and J. Amadon. 1984. A soil test for nitrogen availability to corn. Soil Sci. Soc. Amer. J. 48:1301-1304.

Meisinger, J.J., V.A. Bandel, J.S. Angle, B.E. O'Keefe, and C.M. Reynolds. 1992. Presidedress soil nitrate test evaluation in Maryland. Soil Sci. Soc. Amer. J. 56:1527-1532.

Roberts, S., W.H. Weaver, and J.P. Phelps. 1980. Use of the nitrate soil test to predict sweet corn response to nitrogen fertilization. Soil Sci. Soc. Amer. J. 44:306-308.

Salardini, A.A., L.A. Sparrow, and R.J. Holloway. 1992. The mobility and transformation of soil nitrogen and the relationships between soil and plant nitrogen and yield at different times following application of various nitrogen fertilizers to sweet corn. Austral. J. Agr. Res. 43:1643-1652. 